Uşak Üniversitesi Sosyal Bilimler Dergisi

$2015,8 / 1$

\title{
Bir Anlatı Mecrası Olarak Yeni Medyanın Söyleminde Trans Bireyler ${ }^{\mathrm{i}}$
}

Soner YAĞLI*

\section{Özet}

Toplumsal, siyasal, ekonomik, kültürel ve özellikle teknolojik gelişim ve değişimler medya kavramının yapısında ona içkin olan tüm unsurlarıla birlikte bir farklılaşma meydana getirmiştir. İletişimin toplumsal boyutunun yanı sıra zaman ve mekân bağlamında görme, işitme, paylaşma ve aidiyet duygularını tamamıyla değiştiren yeni medya ortamı, toplumsal cinsiyet çalışmalarının ilgi odaklarından biri olmuştur. Bireyin kendisini hissettiği ve özdeşlik kurduğu cinsiyete dair kimliğinin oluşumunda toplumun ona biçtiği ve görmek istediği, hatta dayattığ roller oldukça etkin olup, bunun dışına çıkıldığında geleneksel biçimde kabul gören "biz" durumunun karşısına geçilerek/itilerek "öteki" olma tehlikesi her zaman mümkündür. Bu ötekileştirme söylemi, günümüzün teknolojiyle bezenmiş/örüntülenmiş ortamında daha yaygın ve etkili bir biçimde karşımıza çıkarak, geniş kitleleri aynı anda sarmalamaktadır. Geleneksel biçimde meşru olarak kabul edilen biyolojik veya toplumsal cinsiyete yönelik anlayışın dışında cinsel yönelimini cinsiyet değiştirerek gerçekleştiren bireyin karşısında günümüz koşullarında daha güçlü bir mecra/cephe yer almaktadır. Yeni medya veya dijital medya olarak da kavramsallaştırabileceğimiz alan, aslında bazen kimi sosyo-kültürel gelişmeler de görüldüğü gibi aynı zamanda desteğin de üretildiği bir platform olmaktadır. Bu bağlamda kadın oyuncu kimliğiyle ün sahibi olan ve "sıradan insan"ın dışında yer alan Rüzgâr Erkoçlar'ın", bir "trans erkek" olarak, kendini erkek gibi hissettiğinden dolayı kadın bedenine hapsolmuşluğunu hormon terapisi ve cinsiyet değiştirme operasyonlarıla

\footnotetext{
i Çalışmada, gerek fiziksel mekân kısıtlılığından ve konunun belirli bir merkezde ele alınması ihtiyacından dolayı, konu bağlamında ele alınan kimi terim ve kavramlar her birinin ciddi bir sorgulamayı hak etme zorunluluğu göz ardı edilmeden bir ön kabul çerçevesinde değerlendirilmiş olup, ana izlek, işlevsel olarak sorgulanması gereken ana kavramlara odaklanılarak yerleşikleştirilmiştir.

Çalışmada, önceki ismi olan "Nil" kullanılmayacak olup tercih ettiği kimlik ve isimden dolayı "Rüzgâr" tercih edilmiştir.

*Yrd. Doç. Dr., Ege Üniversitesi İletişim Fakültesi Gazetecilik Bölümü
} 
değiştirip cinsiyet ve görünüm olarak da erkekliği tercih etmesi yeni medya platformlarında, özellikle twitter üzerinden başlatılan bir tartışmayı gündeme taşımıştır. Söylemsel düzeyde kimi tepkilerden ötürü "ayrımcı söylem" ve "nefret söylemi" içinde de değerlendirilebilecek Erkoçlar'ın cinsiyet değiştirme operasyonu, cinsiyet bağlamında daha yaygın olarak görülen erkek iken kadın cinsiyetini seçme operasyonlarına duyulan tepkinin dışında toplumsal düzeyde "makbul" olan "erkek" cinsiyetinin seçilmesi ve kimi çevrelerce sadece "erkek" unsurundan dolayı bir ön kabul oluşturması bakımından da önemli bir örnektir. Bu ön kabul, sosyal medyayı kullanan bireylerin söylemlerinde çok belirgin biçimde karşımıza çıkmaktadır. Buradan hareketle bu çalışmada, ilgili örnek olay temel alınarak yeni medya söyleminde toplumsal cinsiyet farklılıklarının nasıl inşa edildiği ve bu söylemsel oluşumda seçilen cinsiyete göre sosyo-kültürel bağlamdaki bakış açılarının nasıl farklılaştığı örneklerle sorgulanacaktır.

Anahtar Kelimeler: Yeni Medya, İdeoloji, Toplumsal Cinsiyet, Söylem, Teknoloji.

\section{Discourse on Transgender Individuals as Narratives in the New Media}

\section{Abstract}

Social, political, economic, cultural and especially technological change and development brought with it a substantial change to the structure within which we perceive the notion of media. The so-called new media that not only changed the social dimension of communication but also the ways in which we hear, see, share and develop identities within new contexts of time and space, have soon caught the attention of gender studies. Gender and identities of individuals can easily find themselves in contradiction to traditional gender roles imposed by society, and such individuals can quickly find themselves as the "other" in a world where "us" dominates. Discourses on the other can spread very quick in today's high-tech and high-speed communication environment, and opinions can rapidly hit masses of online users. This causes individuals with notions of gender and identity other than those approved by traditional social and cultural structures to become subject to broad attacks via powerful media channels. On the other hand, and equally strong in power, the same individuals can receive strong support from like-minded people. Within this context, Rüzgâr Erkoçlar, a once famous actress, who recently expressed that she felt like a male and underwent several medical treatments in order to change her sex, has become subject to heatful debate on new media platforms. These debates, who often contained instances that can be defined 
as hate speech and acts of discrimination, displayed on the other hand a stance that was more "forgiving" because the transition took place from the socially less privileged female gender to the more privileged male gender, an attitude which can be labeled as another act of bigotry. These traits in the evaluation of Erkoçlar's gender transition can be clearly followed in the discourse that built up around the debates on the internet. Based on these facts, and the aforementioned case, this study aims to analyse the ways in which gender roles are constructed during the use of new media, and how different social and cultural viewpoints tackle the issue.

Key Words: New Media, Ideology, Gender, Discourse, Technology.

\section{Giriş}

"Hayal, gerçeğe her gidişinde, onu kendisine aykırı olarak bulur: hayalin karşısında duran gerçek..."

O. Aruoba

Yeni medya, geleneksel (konvansiyonel) medyaya göre kendine içkin özelliklerden dolayı daha farklı bir topluluk oluşturmuştur. Medyanın bilinen işlevlerinin çok ötesine geçerek, zaten var olan etkileme ve yönlendirme gücünü iyice arttırması, yeni mecralarda kitlesel hareketlerin ve bu hareketlerin içerisinde yer alanların niceliğinde kendini göstermektedir. Bireysel özgürlügün ve tatminin kitlesel uyum süreci ve özgürlükle eş tutulduğu yeni ortamlar, bireye kendisi gibi düşünen, pek çok şeyi paylaştığı ama fiziksel olarak göremediği topluluklar sunmaktadır. Bu gizemli katılımcılığın dışında yeni dijital platformlar, düşüncelerin paylaşılma hızı ve yaygınlaş(tırıl)ması bağlamında da birey için ilgi çekicidir.

Yeni mecraların ideolojik olarak meşrulaştırılmış düşünceleri sistemin devamına yönelik olarak daha da yaygınlaştırıcı ve pekiştirici gücü, iktidar açısından bir tercih sebebidir. Özellikle çalışma konusu bağlamında erkek egemen ideolojinin üzerinde uzlaştı̆̆ 1 ve sürekli olarak ürettiği toplumsal cinsiyet bağlamında kadına olan bakış açısı bu yeni platformlarda da yeniden yeniden üretilmektedir. Daha da özelde dikkat çekici olan şey, makbul ve kabul edilmiş kimlikler ile makbul olmayan ve ötekileştirilmiş kimlikler arasındaki çatışmadır, buradaki söylemsel farklılıktır.

$\mathrm{Bu}$ amaçla çalışmada, cinsiyet tercihleri söz konusu olduğunda erkek/eril egemen ideolojinin, erkek kimliğinden kadın kimliğine geçişlerle kadın kimliğinden erkek kimliğine geçişler karşısındaki tutumunu kuramsal bazda ilgili kavramlarla sorgulamak, Rüzgâr Erkoçlar'ın cinsiyet değiştirme 
operasyonu örneği üzerinden Twitter'da paylaşılan tweetleri değerlendirerek öne sürülen görüşlerin pekiştirilmesi amaçlanmaktadır.

Yeni Medya Yeni Söylem ve Teknik Akılsallığın Tahakkümü

$$
\begin{array}{r}
\text { "Günümüz teknik akılsallığg } \\
\text { egemenliğin akılsallığıdır" } \\
\text { T. Adorno }
\end{array}
$$

Bilgilendirme, eğlendirme, yorumlama, gerçeğin bulunmasına yardımcı olma ve iktidarı kamu adına denetleme gibi klâsik işlevlerinin üstüne çıkan günümüz medyası, etkileme ve yönlendirme işlevini daha öne çıkararak işlemektedir. Bu durumu ortaya çıkaran en önemli unsurlardan biri de teknolojinin sürekli olarak yenilenme hızının ivme kazanmasıdır. Geleneksel (konvansiyonel) medyanın özellikle teknolojik gelişim ve değişim sonucu kendine içkin özelliklerini daha da geliştirerek yeni medya olarak adlandırılan yapıya geçiş yapmasıyla toplumsal, siyasal, ekonomik ve kültürel bağlamdaki karşılıklı etkilenme ve etkilemenin niteliği ve hızı da değişmiştir. Birincil sözlü kültür ile ikincil sözlü kültürü ayırırken gizemli katılımcılık, zaman ve fiziksel mekân sınırlarının ortadan kalkmasıyla birlikte farklı bir sosyalleşmeye ve topluluk duygusunun güçlenmesine dikkat çeken Ong'un (1995) bu ayrım noktaları, yeni teknolojinin ortaya çıkardığ olmasına yol açmıştır.

Öncelikli olarak yeni medya dediğimiz mecranın neyi ya da neleri, hangi platformları kapsadığına bir cevap aranırsa, internet ortamıla birlikte, oyun konsolları, cep telefonu, avuç içi veri bankası kayıtlayıcı ve iletişimcileriyle birlikte İpod'u içeren dijital teknolojilerin tümünü yeni medya olarak adlandırmak mümkündür. Multimedya formatına sahip ve etkileşimli olması yeni medyayı geleneksel medyadan ayrımlaştıran bir özelliktir (Binark, 2007: 21). Yengin'e göre (2012); yeni metinsel deneyimlere, dünyayı temsil etmenin yeni yollarına, öznelerin medya teknolojileri ile arasındaki ilişkilere, somutlaşmaya, kimlik ve topluluk arasındaki yeni ilişki deneyimlerine, biyolojik vücudun teknolojik medya ile ilişkisine dair yeni kavrayışlara, yeni kuruluş ve üretim modellerine gönderme yapan yeni medya, kullanıcı türevliliği, dijital olması, etkileşimliliği, hipermetinselliği, sanallığ ve ağ bağlantılılığ 1 içermektedir.

Olabildiğince huzlı olan ve tüketme odaklı internet, duygu ve düşüncelerimizi iletebileceğimiz kişilerarası medya olanaklarını sunarak özel bir toplumsallığın daha güçlü bir hale gelmesini sağlar ve bir bütün olarak çıkar grupları, beğeni kültürleri ve kültürel topluluklarla evrensel bir biçimde bütünleşme ya da ayrımlaşma yaratır. Internet, talep mantığını 
değil arz mantığını karşılar ve kamusal alan açısından birleştirici olmaktan daha çok parçalayıcıdır. Kendi başına düşünmeyi olanaksızlaştıran yeni medya ortamında, düşünce, bireyin başkalarına inanmaya başladığı an oluşur. Bilgi açısından yorucu, yalnızlaştıran ve üretkenliği sanıldığından daha düşük olan yeni medya, bireyi yanlışa sürükleme ihtimalinin yüksekliği nedeniyle de dikkat çekicidir. Bu yeni mecranın ana mottosu "birlikte görmek" üzerine inşa edilmiştir. Başkalarının neyi ilginç bulduğu, neyi benimsediği, neyi görüp tartıştı̆̆ ve bunlar üzerinden katılımda bulunmak önemlidir (Maigret, 2011). Bireysel bağlamda, yeni medyada geçerli olan ve öne çıkan; başkaları için bir şeyler yapmaktır. Merak duygusuyla gözetlemenin ve seyretmenin yanı sıra her şeyin seyirlik olduğu ortamda aslında ifşa etmek, kendini seyrettirmek de öne çıkmaktadır.

Mesajın, iletişim aracı olduğu yeni medya düzeninde, iletişim araçları ve alımlayıcı kitlenin çeşitliliği oldukça öne çıkmış olup, mesajın özelliği iletişim aracının niteliğini ve özelliğini belirler. Günümüzde bireyselleşmenin arttığı, toplumsal çözülmenin ivmesinin hızlandığ ortamda yeni medya mecrasi, bir özgürlük teknolojisi olarak toplumsal bağları da birbirine bağlayan bir özellik göstermektedir (Castells, 2013): Yeni teknolojiler kapsamında bir araya gelen toplulukların diğer fiziksel topluluklardan paylaşılan ortamdan dolayı belirgin farklılıkları vardır. Birer cemaat olarak nitelendirilebilecek bu topluluklar arasında, sanal ortamda fiziksel ortama göre bazen daha güçlü bir bağ kurulabilmektedir. Fiziksel cemaatler için geçerli olan kalıp ve yöntemleri izlemeyen sanal cemaatlere yönelik olarak, kendi içlerinde farklı bir gerçeklik düzlemi bulunduğunu söylemek mümkündür. Kendi dinamiği olan bu ağlar, zayıf bağlara dayanıyor gibi görünse de çeşitliliği artmış, uzmanlaşmış, güçlü etkileşim ve destek üretebilen, aynı zamanda kişisellik özelliğine sahip ağlardır. Tam da Barthes ve Baudrillard'ın savuna geldiği üzere, gösterge üretimi ve tüketimciliğin ön planda olduğu bu ağlar, gerçek sanallık kültürünü inşa etmekte olup düşük maliyetle oldukça önemli mesafeleri aşmaktadır.

Teknolojinin gelişimi ve değişimi, yeni iletişim teknolojilerinin yarattığı demokratikleşme ve özgürlük potansiyelinin ötesine geçerek kimi zaman kamusal iletişimi, toplumsal dayanışmayı zedeleyerek, kültürü ticarileştirebilir. Özgürlük de bu bağlamda denetim ve gözetimin bir amacı haline gelebilir (Aydoğan, 2010: 4-5). Burada dikkat çekici olan şey, bu olumsuzlukların bertaraf edilmesine yarayacak bir biçimde, bireyin bunu algıla(ya)mayacak seviyeye çekilmesidir. Bu da, herkesle aynı şeyi yapıyor olmak ya da aynı duyguyu paylaşmak üzerinden üretilen kitlesel uyum süreci sonucundaki bireysel hazda sağlanmaktadır. Bireysel özgürlük hissi kitlesel uyum sürecine bağlı kalmaktadır. 
Teknolojinin, kültürel pratikleri değiştirme ve dönüştürme potansiyeli göz önüne alındığında, buna bir de toplumsal düzeydeki örgütlenme biçimlerine etkisi eklendiğinde salt bir teknik olgu ya da kullanıma ilişkin bir düzey olmadığı apaçıktır. $\mathrm{Bu} \mathrm{da,} \mathrm{günümüzde} \mathrm{teknolojinin} \mathrm{ve} \mathrm{onun}$ biçimlendirdiği medyanın tıpkı geleneksel(konvansiyonel) medya gibi, bir bütün olarak, toplumsal, siyasal, ekonomik ve kültürel bağlamlarıyla çözümlenmesini dayatır. Aslında bütün bunların ötesinde daha önemli bir kavramın sorgusu daha açımlayıcı olacaktır; ideoloji ve meşrulaştırmanın nasıl gerçekleştirildiği. Özellikle siyasal olanın karşısında gittikçe öne çıkmaya başlayan ekonomik süreçlerin ideolojik meşruiyet baskısı, teknolojinin öne çıktığı gündelik hayatın kültürel pratiklerinde düzenin sürekliliği için aynı zamanda bir denetim ve gözetim mekanizmasını da oluşturmaktadır. Ergur (1998), sözü edilen çoğulluğun aslında birbirine benzeme durumundan kaynaklı bir özdeşleşme ve bunun heryerdeliği olduğuna vurgu yapmaktadır: Günümüz teknolojisi ve onun yarattığ medya mecrası gündelikliğimizi kolaylaştırıyorken tam karşıt bir noktadan da hayatımızı kurgulamaktadır. Tüketimcilik ideolojisi içinde tüm kurgulama gereksinim yaratmaya yönelik olmaktadır. Bu bağlamda, özgürleştiren teknolojinin özgürleştirme sınırları da sorgulamaya açılmalıdır. $\mathrm{Bu}$ gerçekleştirilirken bireylerin kendi rızalarıyla nasıl bir manipülasyona tabi tutuldukları, denetleme ve gözetleme sorunu ve bu standartlaştırılmış özgürlügün çerçevesi önemlidir. Kitlesel aynıdalık bireyselliğe giden yolda özgürlük gibi algılanmakta, internetin karşı konulamaz davetkârlığı da cennete giden kapıyı oluşturmaktadır.

Küresel iletişim sistemlerinin sayesinde kendi bulunduğu yerel ortamdan küresel mecralara açılan birey, diğer bireylerle etkileşimini arttırmış görünse de, kimi zaman sisteme zararlı olan çoğu görüş, düşünce ya da eylemsel pratik evcilleştirilmekte, bütünleşik hale gelen bu uysallaşmış tutum, davranış ve düşünceler yaygın hale dönüşmektedir. Denetimden kaçarken aslında başka türden bir denetim ve gözetimin içerisine giren birey, bunu farkındalığına varamayacak bir seviyeye çekilmiştir (Ergur, 1996). Bütünüyle yeni teknolojilerin bu durumu yarattı̆̆ 1 yanılsamasına düşmeyip, yeni mecranın denetleme ve gözetleme kültürüne olanak sağladığı düşüncesini de göz ardı etmemek gerekmektedir.

Denetim ve gözetimin olduğu her alan da bir iktidar sorunsallaştırması söz konusudur. Yeni teknolojilerin özgürleştirici ve anarşist karakterini, iktidardan taleplerini dile getirici bir mecra olduğu gerçeğini gözeterek, tam karşıt açıdan iktidarın da bireyleri kontrol etmeyi bu yolla tercih edebileceğini belirtmek gerekmektedir. Bu yeni mecra, herkes içindir, herkesin amacı içindir. İktidarın, toplumsal bir denetim aracı olarak 
gördüğü yeni medya, bireylerin kişisel enformasyonlarının sergilendiği, kamusal ve özel alan çatışmasının yaşandığı, hatta özel alanın daraldığı bir yer de olabilir. Özellikle kültür ve ideoloji bağlamında, hissettirmeden gerçekleştirilen denetim ve gözetim, bunun sonucunda kayıt altına alma birey için kişisel haklar açısından tehlikeli bir durum yaratmaktadır (Bozkurt, 2000). Yeni teknolojinin kullanıldığı yeni medya, özgürlükler bağlamında, geniş bir ifade alanı olduğu kadar, alanı ve sınırları belli olmayan bir denetleme ve gözetleme kültürüne de neden olmaktadır.

\section{(Yeni) Medya Çalışmalarında İdeolojinin Baskınlığ $1^{\mathrm{ii}}$}

"Yaşamak, yan tutmak demektir."

A. Gramsci

Kültürün içinde doğduğu, geliştiği, yayıldığ 1 ve paylaşıldığ 1 coğrafyanın toplumsal, siyasal, ekonomik bağlamları belirleyici olmaktadır. Bütün kültürel kodlamalar ve buna uygun açımlamalar hep bu unsurlara göre biçimlenmektedir. Oldukça geniş bir sorgulama alanına sahip bir kavram olan kültür, anlam ve iletişim ilişkisinin çözümleyebilmek için bir başka sorunsaldan, ideoloji kavramından konuyu açımlamak çalışma bağlamında daha işlevsel olacaktır (Kellner, 2005: 234). Çünkü kültür ve ideolojinin farklı türleri, biçimleri, etkilerinin iyi analiz edilmesi sosyokültürel bağlamındaki yerleşik meşrulaşmış uzlaşımları kavrayışta önemlidir. Sosyo-kültürel gündelik pratikleri meydana getiren, dolaşıma sokup onların geniş kitlelerce paylaşımında önemli rol oynayan mecralardan biri, hatta en önemlisi iletişim araçlarıdır. Özellikle teknolojinin gelişimi ile yeni medyanın ortaya çıkışı bu yöndeki hızı oldukça arttırmıştır.

Kültürü oluşturan, inşa eden en önemli mecralardan biri dildir. Dil üzerinden bir paylaşım yapılır ve her şey onun içerisinde kodlanır. Bu nedenle iletişim ortamlarında kullanılan dilin niteliği, ne paylaşıldığı, nasıl ve niçin bu biçimde örüntülendiğini değerlendirmeye almak, böylesi bir sorgulama arka plan bilgisini, ardalanı da içereceği için araştııılan mevzular için daha açıklayıcı olmaktadır. Dil üzerinden bir değerlendirme yapacak olursak, dilin, gerçekliği insan zihninde yansımasını sağlayan basit bir araç olmadığını, doğrudan o gerçekliğin kuruluşunda etkili olan toplumsal bir pratik olduğu söylemek mümkündür. Anlamın dil içerisinde harekete geçmesiyle ortaya çıkan şeyi söylem olarak tanımlarsak, söylem içindeki

ii İdeoloji sorunsalına ilişkin bir izleğin oluşturulması terimin kendine içkin niteliğinden dolayı oldukça zorludur. Bundan dolayı bu çalışmada ideolojiye ilişkin olarak konu bağlamında işlevsel değerlendirmeler yapılmıştır. 
anlamın belirli kişi ya da gruplar lehine nasıl harekete geçtiği de ayrı bir tartışma konusudur. Burada söz konusu olan; bu lehte harekete geçmeyi ifade eden ideolojidir. Dil, anlam, düşünce ve gerçekliliğin olduğu her alanda temsil, dolayımlama, imgelem/tahayyül ve simgeleme önemlidir. İdeoloji, bunları gerçekleştiren bir nitelik taşımaktadır. (Üşür, 1997: 74, 89). Fowler (1985: 64), dilin, sosyal pratiği inşa eden bir gerçeklik olduğunu belirterek, anlatıcının da bu söylemsel düzenin içinde kurulduğunu ve konumlandığını söylemektedir. Fowler'e göre (1991: 42), söylem, dil içerisinde kodlanmış, toplumsal ve kurumsal kökenli bir ideolojidir.

Toplumsal kurum ve pratikleri destekleyen ideoloji, aynı zamanda onları kalıcı hale getirir ve bir meşrulaştırma biçimi olarak, düzenli bir tahakküm ve hegemonyayı da yerleşik kılarak meşrulaştıran bir dünya resmi (world-picture)'dir (Geuss, 2002: 29). Mumby (2005), ideolojinin kaygan ve ele avuca sığmayan bir şey olduğuna çekerek, aslında ideolojinin iktidar ve anlam ilişkilerinin çözümlenmesinde son derece önemli olduğunu belirtir. Belirli egemenlik ilişkilerinin üretiminde ve yeniden üretiminde baskın olan ideoloji, toplumsal dünyanın derinlerine yerleşikleşerek, toplumsal gerçekliğin kurucusu haline gelir. Gündelik hayata dair olan her bu gerçeklik penceresinden algılanır. Gerçekliğin toplumsal olarak kurulmasında önemli bir işlevi olan ideoloji, bireye kendiliğinden yerleşikleşmez.

İdeoloji, Eagleton'un (1996) düşüncesinde; maskeleme, rasyonalize etme, doğallaştırma, evrenselleştirme ve meşrulaştırma işlevlerine sahiptir. Bunu gerçekleştirecek bir diğer alan da dildir. Dilsel yapıların önemli olduğu ve anlatının ortaya çıktığı yer olarak dilin öne çıtığı anlam inşası çok geniş bir alana sahiptir. Basitçe gösteren ve gösterilen ikiliğinin özdeşleşmesine bağlı olan bu alanda gerçeklik ortaya çıkmaktadır. (Yeni) medya, bu gerçekliğin ve yeni kültürel biçimlerin ortaya çıkmasında ve inşasında var olan kültürel yapıyı da gözeterek tepkisini geliştirmektedir (Lundby, Roonning, 1997): Yeni değerlerin üretiminde hiçbir zaman sosyal bilgi stokumuzda yer alan kültürel kavramlar, temsiller, uzlaşımlar ve sınırlar gözden kaçırılmaz.

Marksizmin klâsik ideoloji tanımlamasında, üretim araçlarını elinde tutan yöneten sınıfın dünya görüşünün yönetilenler tarafından doğal ve meşru kılınmasını sağlayan ideoloji, Gramsci'de, hegemonya kavramı ile birlikte açımlanmıştır (Üşür, 1997): Marks'ın düşüncesini egemen ideoloji tanımıyla daha da genişleten Gramsci, sadece siyasi ve ekonomik bir kontrolden bahsetmeyip, egemen bir sınıfın düşüncesinin toplumsal düzeyde her alanda yaygınlaşmasına vurgusunu yapar ve bunu da hegemonya ve rızayı üretme kavramlarından yola çıarak gerçekleştirir. 
Kontrolü elinde tutan güç ya da güçlerin kendi dünya görüşünü alttakilere benimsetme amacıyla ortay çıkan hegemonya, bunu gerçekleştirirken rizaya dayalı bir biçimde yapmaktadır. Kültürel değerlerin de egemenin düşüncesine görme biçimlenmesini sağlayan hegemonya, sürekli bir biçimde yeniden ve yeniden üretilmektedir. Tüm gerçeklik tanımlarının rızaya dayalı bir biçimde yeniden üretildiği hegemonik yapıda açıkça bir kontrol görülmediği için bireyde yanıltıcı bir özgürlük hissini oluşturabilmektedir. Hegemonyayı sağlayan, üreten, pekiştiren, yenileyen, yeniden üreten en önemli mecralardan biri, medyadır. Özellikle teknolojinin gelişimiyle birlikte yeni medya araçlarında baskın olan düşünce ve pratikler oldukça hizlı bir onay görmekte, diğerleri ise ötelenmekte ve dışlanmaktadır. Egemenin dışında kalanların marjinal, sıradışı, öteki ya da meşru olmayan olarak tanımlanması sonucu bu düşüncesinin yaygınlık kazanıp onanması, yeni dijital platformlarında daha hızlıdır ve paylaşım ve yaygınlık düzeyi daha yüksektir.

"Tanıma/kabul etme", "özneleştirmeltâbi kılma" ve "güvence" kavramları ile ideolojinin etkisini ortaya koyan Althusser, Devletin İdeolojik Aygitları (DİA) ve Devletin Baskı Aygitları (DBA) ayrımını yaparak, ideolojik aygıtların ideolojiyi kullanarak işlediğine ve baskının ikincil planda yer aldığına dikkat çekmektedir (2003): İdeolojik aygitlarda bireylere egemenin düşüncelerine uygun olarak toplumsal kimlikler giydirilerek, sosyo-kültürel bağlamda kabul edilmiş meşru tanımlamalar ve adlandırmalar yapılır. Birey, kendini bu aygitlar vasitasıyla adlandırır. Çağırma ve çağrılma kavramlarıyla kendi başına özerk olmayan bireyler belirli kodlamalar içerisinde tanımlanır. Bu tanımlamalar hep egemen düşüncenin pekiştirilmesine ve yeniden üretilmesine ilişkindir. Kişileri çoğu zaman nesneleştiren bu durum (yeni) medya söyleminde konumuz bağlamında trans bireyler özelinde sıkça görülmektedir.

\section{Trans Erkek Kimliğine İlişkin Olarak "Rüzgâr Erkoçlar" Örneğinde Yeni Medya Söylemiiii}

“...Hiçbir dil yoktur ki aldatmasın."

I. Calvino

Toplumsal kimlik ve cinsiyet algısı oldukça sorunsal bir alan olup, bireyin egemen düşüncenin dışında bu bağlamda kendisini ifade etme

\footnotetext{
iii Bu çalışmanın amacl; trans kavramının ne olduğu, ya da trans erkek ya da kadın tanımlamalarındaki karmaşık duruma yönelik açıklamalar yapmak değil, Rüzgâr Erkoçlar örneğinde, yeni medyada, twitter özelinde yer alan egemen eril söylemin nasıl temsil edildiğine dair saptamalarda bulunmaktır.
} 
biçimlerinin sosyo-kültürel bağlamda ciddi biçimde sorgulanmasına neden olan kavramları ve düşünceleri barındırmaktadır. Birey kendini tanımladığı ya da kendisine yerleşikleş(tiril)en kimlik, rol ya da cinsiyet ifadelendirilmesine göre kendini rahatsız ya da güvende hisseder. Egemen bakışaçısına karşı kendini öteki hissetmek ya da onlardan biri olarak görmeyi sağlayan bazı süreçler söz konusudur (Demirtaş; 2003): Kimliğin oluşumunda kendimizi belirli kategorilere yerleştirmenin önemine vurgu yapan kategorilendirme, belirli bazı grup ya da kişilerle özdeşleşme, bireyin kendisini başka gruplarla kıyaslayarak içinde bulunduğu gruba aidiyetini ve lehte davranışlarda bulunmasını sağlayan karşılaştırma ve sahip olunan kimliğin diğerlerinden farkına yönelik olarak onu olumlu bir tercih olarak görmemize olanak veren psikolojik ayrıştırılabilirlik. Bütün bu süreçler bireyin cinsiyet tercihi bağlamında etkili olmakta, diğerleri tarafından da yargılanma noktasında öne çıkmaktadır. Toplumsal cinsiyet kendisi zaten sorunlu bir kavram iken, cinsiyet tercihleri sosyo-kültürel bağlamda daha da karmaşık bir analizi zorunlu kılmaktadır.

Scott (2007), toplumsal cinsiyetin tarihsel analizini ortaya koyarken bunu toplumsal, siyasal, ekonomik ve kültürel bağlamlarla birlikte değerlendirmenin işlevsel olacağına vurgu yapmaktadır:

"Toplumsal cinsiyet, cinsler arasinda kavranabilen farklliklara dayal toplumsal ilişkilerin kurucu ögesidir ... iktidar ilişkilerini belirgin klmanin asli yoludur... her zaman iktidarın farkl temsillerindeki değişikliklere tekabül eder... toplumsal cinsiyet, birbiriyle ilişkili dört ögeyi içinde barındırır: İlki çoğul (ve çoğunlukla çelişkili) temsilleri hatırlatan kültürel simgelerle ... birlikte aydınlık ve karanlık, arınma ve kirlilik, masumiyet ve yozlaşma mitleri... İkincisi, söz konusu simgelerin anlamların ve nasıl yorumlandıkların ortaya koyan, metoforik olasılikları sinırlamayı ve içermeyi amaçlayan normatif kavramlardır... din, eğitim ve bilim... çoğunlukla değişmez bir ikili karşıtllk biçiminde ortaya konur... Böylesi bir analiz kaçınılmaz olarak siyaset kavramını içermeli ve toplumsal kurum ve örgütlenmelere - toplumsal cinsiyet ilişkilerinin üçüncü veçhesi- referans vermelidir. Toplumsal cinsiyetin dördüncü ögesi öznel kimliktir".

Erkekliğin fiziksel tanımını yapmak basit bir şey değildir (Connell, 1998): "Boy pos ve şekli, tavır ve hareket alışkanlıkların, belirli fiziksel becerilere sahip olmayı ve belirli becerilerin eksik kalmasını, kişinin kendi beden imajını, bunun öteki insanlara sunuluş biçimini ve bu insanlarm buna karşllı verme biçimlerini, kişinin bedeninin çalı̧̧ma ve cinsel ilişkilerdeki işleyiş biçimini içerir. 
Bunlarm hiçbiri, hiçbir anlamda XY kromozomlarmın sonucu değildir." Toplumdaki erkekler tarihsel süreçte devlet aracılığıyla genel olarak hep üstün tutulmuşlardır. Erkeği ailenin (hane) geçimini sağlayan birey olarak inşa etmek genel kabul gören ve meşrulaştırılmış bir öngörüdür. Kadınların akıl yürütmede yetersiz ve duygusal bozukluk eğilimi yüksek olarak değerlendirilmesi bu bakış açısının bir ürünüdür. Ailenin düzenlenmesi ve denetlenmesi aynı zamanda hem düzeni koruyan hem birey ile toplum arasındaki ilişkileri düzenleyen hem de cinsiyet farklığına yönelik düşünceleri yerleşikleştiren bir durum yaratmaktadır (Pelizzon, 2009: 376). Erkek egemen bakışaçısı kendini makbul olarak kurarken, kadını bir karşı kimlik olarak öteki ve makbul olmayan kategorisine sokmaktadır.

Kimi toplumsal cinsiyet kimlikleri kültürel temelde idrak edilebilir olmadığından, ya da kültürel bağlamda ortak kodlanmış ve onaylanmış kimliklere yerleşikleştirilemediği için gelişimsel hatalar ve mantıksal olanaksızlıklar varmış gibi kabul edilmektedir. Toplumsal cinsiyetin alımlanmasındaki karmaşa onun heteroseksüellik üzerinden tekbiçimli olarak kavranmasına yönelik bir birlik anlayışının olmasından kaynaklanmaktadır. Heteroseksüelliğin dışında biseksüellik ya da eşcinsellik iktidarın dayatmasının dışında tekliği yıkan bir şeydir (Butler, 2012). Eril egemen akıl, kadını daha ikincil planda tutmaya gayret ederken, farklı cinsiyet tercihleri karşısında söylemini daha da sertleştirir ve onları daha da yıkıcı bir biçimde toplumun önüne ikinci sınıf bir birey olarak atmaktan çekinmez. Çünkü farklı tercihler, kabul edilegelmiş sistem için tehlikedir.

Erkekliğin bedensel anlamının hedefi özellikle erkeklerin kadınlar karşısındaki üstünlüğüdür, kadınlara egemen olmak için gerekli olan şey de hegemonyacı erkekliktir (Connell, 1998): İktidarı elinde bulunduran erkeğin toplumsal tanımı, sadece zihinsel beden imajları ya da fantezilere değil, kas gücüne, duruşa, beden duygusuna ve dokusuna da dönüşmektedir. Gramsci'nin hegemonya kavramından yola çıkarak geliştirilen hegemonik erkeklik, güç ve zenginliğin belirli erkek grupları tarafından nasıl elde tutulduğunu, tahakkümün bu yolla toplumsal ilişkileri nasıl meşrulaştırdığını ve yeniden nasıl ürettiğine vurgu yapmaktadır. Erkeklerin egemen, kadınların tabiyet içinde yer aldıkları bu toplumsal düzen cinsiyet pratiklerinde de kendini göstermektedir.

Toplumdaki kontrolün ifadesi ve uygulaması olan erkeklik olgusu bir yönüyle "kadın olmayış" ile kendini tanımlamaktadır. Bu durum erkekliğin kendi iç cinsiyet politikalarında da kendini göstermektedir. Eşcinsel erkekler egemen/hâkim erkek ideoloji içerisinde dışlanan, hatta saldırıya uğrayan ve kadınsı olma potansiyeline sahip bir gruptur 
(Zeybekoğlu, 2013). Erkek ve kadına, eril ve dişiye yönelik anlam inşaları şüpheye yer bırakmayacak biçimde sistematik olarak belirlenir (Scott, 2007: 38-39). Kadına bir güç mücadelesi içinde düşmanca bakan cinsiyetçiliği tetikleyen eril söylem sürekli olarak üretilmektedir (Fine, 2011: 87). Hetereoseksist baskıcı tutum, kız çocukları ya da kadınlara toplumsal cinsiyet eşitsizliğini erkek egemen kültürün tüm şiddetiyle yaşatmaktadır (Köylü; 2012). Aslında söz konusu olan kadınlara karşı girişilen basit bir dışlama değil, kadınlığın bu dışlama yoluyla üretilmesidir. Kadınlar özel bir alan içine hapsedilerek özellikle baskı altına alma üzerinden tanımlanan bir kimlik taşımaktadır. Eril düşünme tarzlarından ve eril olandan dışlanma, "kadınsı olanın" küçük düşürülmesidir (Lloyd, 1996: 135). Kadınsı olmanın küçük dürülmesi cinsiyet tercihlerinde daha da sert bir biçimde kendini dayatır. Makbul kimliğin terki affedilecek bir eylemsel durum değildir. Aksine egemen düşünceye bir tehdit olarak algılandığ 1 için meşrulaşmış bir saldırıya da davet edicidir.

İktidarı elinde tutan grupların kendilerine ayrıcalık tanıyan yapıyı ve düzeni yeniden üretmeye çalışması ve bunun için pratiklerde bulunması gayet doğaldır (Connell, 1998: 73). Sistemin kendi güncel varoluşu ve sürekliliğini tehdit eden her ne varsa bertaraf etmek istemesi, geleneksel kadın-erkek ikiliğinin dışında kalan kimliklerin doğal olmayan durum olarak değerlendirilmesine neden olur (Ördek, 2012: 312-313): Trans kimlikler özelinde de söz konusu olan genel ahlâka aykırılık, kamu düzeni, ahlâki değerler ve doğal olmayan durum kıstasları özellikle medyadaki etkin figürlerin söylemlerinde de yerleşik bir biçimde yer almaktadır.

Toplum içinde öteki olarak adlandırılan gruplara karşı beslenen önyargılarla birlikte bu gruplara aidiyet besleyenlerin aşağılanması, küçük düşürülmesi, hedef gösterilerek nefret edilmesi bunu sağlayan ve bu söylemi üreten gruba güç ve özen atfetmesi bağlamında olumlu bir durum değildir. Esas olarak, söylenenlerin dışında, söylen(e)meyenler, normal, mantıklı ve rasyonel gözüken şeyler nefret söyleminin teşhis edilmesini zorlaştırır (İnceoğlu ve Çoban, 2014: 71). Gündelik hayatta sıkça rastlanılan, trans bireylere ilişkin eylemler ve bunların medyadaki yansımaları bu durumu izah etmede oldukça açımlayıcıdır. Trans bireyle ilişkiye giren adamın tam tersi bir ilişki teklif edildiğinde cinayet işlemesi, trans bireyi öldüren bir başka kişinin bunu yanındakilere de onaylatmaya çalışması ve iyi bir şey yaptığına inanması oldukça sık rastlanan örneklerdir.

Cinsiyet mevzusunda ayrımcı/nefret söylemine en çok maruz kalan toplumsal cinsiyet çalışmalarının öznesi (belki de nesnesi) olan kadına yönelik baskının tezahürü, özellikle cinselliğe yönelik ideolojiler söz konusu olduğunda çok daha acımasızca görülmektedir. Normal kabul edilen, 
makbul, onanmış, kimliklerin dişındaki cinsiyet tercihleri herhangi bir meşru, üzerinde uzlaşılmış, sistemin izin verdiği bir kimliğe sokulamadığından cinsel tercihi ne olursa olsun bu kişiler, ya homoseksüel ya da lezbiyendir. Konu bağlamında ele alınan trans kimlikler daha henüz belirli kategorilendirme ya da kabul edilebilir olma durumunda hiç değildir.

Medyadaki cinsiyetçi, homofobik ya da transfobik söylemin inşası söz konusu olduğunda olumsuz olarak değerlendirilebilecek ana başlıkları şu biçimde toplamak mümkündür (Kaos GL, 2012: 304-305): LGBT bireylerin cinsel obje olarak görülmesi, onların ve olayların kriminalize edilmesi, eşcinselliğe ilişkin stereotiplerin beslenmesi, haberlerin dilinin homofobik olması, LGBT bireylere yönelik şiddetin meşrulaş(tırıl)ması, bu bireylerin karikatürize edilmesi, mağdur olduklarında küçük düşürücü ifadelerin ve fotoğrafların/görsellerin kullanılması, saldırıya uğradıklarında sadece saldırganın ifadesinin ön plana çı(artıl)ması, kullanılan görsellerin önyargıyı pekiştirmesi, kullanılan kelimelerdeki yanlışlık, ayrımcı ya da nefret söyleminin yayılması ve başka gruplara ayrımcılık yapmak için eşcinselliğin kullanımı.

Konunun geldiği nokta itibariyle, özellikle Twitter'da, Nil Erkoçlar adı ile kadın kimliğinde iken, trans erkekliği seçen Rüzgâr Erkoçlar'a ilişkin atılan tweetler, sözü edilen erkek egemen ideolojinin nasıl işlediğine işlevsel bir örnek teşkil edecektir. Sosyal medya mecrası olarak Twitter'ın çoğu toplumsal olayda ciddi bir haberleşme mekânı olması, anındalığı, hızı, paylaşım yüksekliği, geri bildirim olanağını hemen sağlanması ve mesajların karakter sınırlamasından dolayı net verilme zorunluluğu onu diğerlerine göre çalışma bağlamında öne çıkaran nitelikler olmaktadır. Bu konuda atılan pek çok tweet bulunmakta olup, fiziksel mekân sınırlamasından dolayı işlevsel ve çarpıcı olanlar kimi tweetler aşağıda yer almaktadır:

"Bu ülkede Rüzgar Erkoçlar gibi bi gerçek var... Taş gibi adam lan.", "o kızdı erkek oldu dediğiniz 'Rüzgar Erkoçlar' bile bir sürü erkekten daha yakışıklı oldu be $\odot$ ", "Rüzgar Erkoçlar bile 26 yıl sonra erkek olup 1 yıl içinde sevgili yaptl, biz hâlâ yalnızlğga tur bindiriyoruz.", "Aklıma ne geldi. Rüzgar Erkoçlar erkek oldu ya. Yani şimdi kadın ruhuna ne muazzam hitap ediyordur he. Bi de yakışıkl çocuk. Ben okeyim.", "Malzeme kaliteliymiş amk kızken güzel erkekken yakışıkl Rüzgar Erkoçlar", "Rüzgar Erkoçlar yeni haliyle bana 10 basar! Açık ve net!", "Rüzgar Erkoçlar senden benden yakışıklı oldu yalnız aga.", "Bu nil erkoçlar senden benden hayli hayli yakışıklı olmuş", "Çoğu erkekten yakışıklı olmuş. Şahsen dibim düştü", "O değil de asll koyan doğduğum günden beri erkeğim ve yalnızım. Bu Rüzgar Erkoçlar 1.5 yıldır erkek 17 aydır sevgilisi var", "Bu Nil Erkoçlar iyi erkek olmuş la", "Bi tane kız bana cinsiyetini değiştiren Nil Erkoçlar senden daha yakışıklı... 
dediğinden beri psikolojim bozuk", "Rüzgar Erkoçlar bizden yakışıkl oldu", "Ekranlarda yeni jön! Rüzgar Erkoçlar geliyor!".

Tweetler değerlendirildiğinde, erkek egemen ideolojinin makbul kabul etmediği bir kimlikten (kadın) makbul kabul edilen bir üst kimliğe (erkek) geçen Rüzgâr Erkoçlar'ın cinsiyet değiştirme operasyonunun, seçtiği kimlik tercihinden dolayı olumlu bir söylemsel düzeyde değerlendirildiği görülmektedir. Sosyo-kültürel bağlamda, erkek kimliğini bırakıp kadın kimliğini tercih edenlere oldukça sert bir karşı çıkma ve eleştirme davranışını sergileyen eril egemen ideoloji, bu kez daha temkinli davranıp ötekine karşı bizi seçtiği için daha kabul edilebilir bir tutum sergilemiştir. Ancak söz konusu olan cinsiyet değiştirme operasyonu, genel düzeyde gene kabul edilebilir değildir. Tweetler incelendiğinde gizil bir alaycılık da göze çarpmaktadır.

Dilin toplumsal gerçekliği inşa etmesinin ve sosyal bilgi stokumuzda bu gerçekliğin sürekli bir biçimde üretildiğinin bir örneği olarak, tweetlerde, eril dilin oldukça baskın olduğu gözlenmiştir. Söylemsel düzeyde, erkek egemen ideoloji ve erkek aklın, seçilen kimlikten dolayı, tam tersi bir durumda yaygin bir biçimde gerçekleştirilen ahlâki bir sorgulamaya gitmediği, ve üzerinde uzlaşılmış stereotipler üretmediği saptanmıştır. Gene de Rüzgâr Erkoçlar'ın cinsiyet değiştirme operasyonunun geniş bir oydaşmayla kabul edilebilir olduğunu söylemek mümkün değildir. Burada söz konusu olan şey, baskın ve makbul ideolojik kimliğe geçişlerde çok yaygın olmasa da daha farklı bir kabul edişin kendini göstermesidir.

Sonuç

"Oysa hakikat, alaycı bir üzüntüyle temellük edilmiştir."

Adorno

Toplumsal kimlik, rol ve cinsiyet alanı her zaman için medya çalışmalarında önemli bir mecra olmuştur. Özellikle yeni iletişim teknolojileri ile birlikte ortaya çıkan yeni medya algısında toplumsal cinsiyete ilişkin değerlendirmeler daha üst düzeyde yer almaya başlamıştır. Bireysel olarak kendini ifadelendirmenin bir biçimi ve özgürlük alanı da olan yeni dijital platformlar, aynı zamanda denetimin ve gözetimin de farklılaştığı mecralardır. Daha önceden kendini ifade etme olanağ bul(a)mayan kişi, grup/oluşum ya da kurumlar yeni mecrada kendine bir yer edinmiş ve bir karşı çıkış, karşı ses olarak yerini almıştır.

İktidarın denetleyiciliğinin yerel düzeyde kaldığı panoptikon gözetimciliğinden, daha küresel bir denetleme ve gözetleme kültürüne geçmeyi ifade eden, çoğunluğun azınlığı izlemesi (sinoptikon) ve gelişen 
teknoloji ile birlikte en nokta olan, herkesin herkesi izleyebildiği omniptikon aşamasında yeni teknolojiden ve yeni platformlardan iktidar da kendine yönelik olarak, sistemin devamı için yararlanmaktadır. Kamu ve özel alan ayrım çizgisinin belirsizleştiği bu yeni dönem de özellikle sosyo-kültürel bağlamda cinsiyetçi söylemin yeni medyadaki ifadesi ya da ifadeleri yeni gibi görünse de aslında egemen ideolojinin yeniden bir ifşası ve üretimidir. Adorno'nun (2007: 110), “...söz konusu olan, onlara üflenen ruhtur, efendilerinin sesidir" ifadesiyle vurguladığ 1 düşünce, bireyi erkek egemen aklın içerisinde tutarak tüm tanımlamaların ve kimliklerin bu araçsal akıl üzerinden gerçekleşmesini sağlamaktadır. Bu durum tam da, Marcuse'un “insanın Tek Boyutluluğu" ya da Horkheimer'in "Akıl Tutulması" olarak kavramsallaştırdığı her zaman geçerli olan, eril aklın yeniden ve yeniden üretilerek sistemin devamının sağlandığı, pekiştirildiği duruma işaret etmektedir.

Erkek egemen aklın işlediği önemli bir alan olan cinsiyetçi söylemde, cinsiyet değiştirme operasyonlarının tabi olunan kimlik içerisinden nasıl değerlendirildiğine ilişkin, Rüzgâr Erkoçlar'ın cinsiyet değiştirmeye yönelik tercihinin nasıl ve neden öyle alımlandığına dair sorgulama yapan bu çalışmada, eril ideolojinin kabul ettiği makbul kimliğe geçişlerin daha az tepkiyle karşılandığı saptanmıştır. Bunda toplumsal, kültürel, ekonomik, teknolojik ve ideolojik süreçlerdeki değişimin de rolü olduğu yadsınamaz. Erkek kimliğinin karşısında öteki olarak yer alan kadın kimliğine geçişler kabul edilemez ve sert bir biçimde reddedilirken, makbul bir kimlik olan erkekliği seçme durumlarında -dinsel bağlamın dışındatepki olsa da daha bir farklı kabullenme söz konusudur. Erkek egemen düşüncede, fiziksel olarak sonradan erkek olmak da kabul edilebilecek bir durum değildir. Geçerli ve önemli olan; erkekliktir, erkek hegemonyasının devamıdır!...

\section{Kaynakça}

ALTHUSSER, L. (2003). İdeoloji ve Devletin İdeolojik Aygitlarl, A. Tümertekin (çev.), İthaki Yayınları, İstanbul.

AYDOĞAN, F., (2010). “İkinci Medya Çağında Gözetim ile Kamusal Alan Paradoksunda İnternet", İkinci Medya Çă̆ında İnternet, F. Aydoğan \& A. Akyüz (der.), Alfa Yayınları, İstanbul, 3-17.

BINARK, M., (2007). “Yeni Medya Çalışmalarında Yeni Sorular ve Yöntem Sorunu", Yeni Medya Çalışmaları, (der. Mutlu Binark), Dipnot Yayınları, Ankara, 21-44. 
BOZKURT, V., (2000). “Gözetim ve İnternet: Özel Yaşamın Sonu mu?", Birikim Dergisi, Say1: 136, 69-74.

BUTLER, J., (2012). Cinsiyet Belası - Feminizm ve Kimliğin Altüst Edilmesi, B. Ertür (çev.), Metis Yayıncılık, İstanbul.

CASTELLS, M., (2013). A ̆̆ Toplumunun Yükselişi - Enformasyon Çă̆ı: Ekonomi, Toplum ve Kültür, E. Kılıç (çev.), İstanbul Bilgi Üniversitesi Yayınları, İstanbul.

CONNELL, R.W. (1998). Toplumsal Cinsiyet ve İktidar - Toplum, Kişi ve Cinsel Politika, C. Soydemir (çev.), Ayrıntı Yayınları, İstanbul.

EAGLETON, T., (1996). İdeoloji, M. Özcan (çev.), Ayrıntı Yayınları, İstanbul.

ERGUR, A., (1996), "Bireyin Son Kaleleri Düşüyor: Cep Telefonu ve Ötesi”, Birikim Dergisi, Sayı:89, 15-22.

ERGUR, A., (1998). "Elektronik Denetimin Sınırlarında Demokrasi", Birikim Dergisi, Sayı:110, 54-59.

FINE, C., (2011). Toplumsal Cinsiyet Yanılsaması, K. Tanrıyar (çev.), Sel Yayıncilık, İstanbul.

FOWLER, R., (1985). Language as Social Practice, Handbook of Discourse Analysis, T. van Dijk (ed.), V: 4, Academic Pres, London.

FOWLER, R., (1991). Language In the News: Discourse and Ideology In the Press, Routledge, London.

GEUSS, R., (2002). Eleştirel Teori - Habermas ve Frankfurt Okulu, F. Keskin (çev.), Ayrıntı Yayınları, İstanbul.

INNCEOĞLU, Y. \& Çoban, B., (2014). "'Öteki'leştirme Sürecinde Medyanın Yeri", Azınlıklar, Ötekiler ve Medya, Ayrıntı Yayınları, İstanbul, 50102.

KAOS GL, (2012). "Nefret Suçları Kimin Sorunu? LGBT Bireyler, Nefret Söylemi ve Medyadaki Temsil", Nefret Söylemi velveya Nefret Suçları, Y. İnceoğlu (der.), Ayrıntı Yayınları, İstanbul, 289-306.

KELLNER, D., (2005). “Kültür Endüstrileri”, Kitle İletişim Kuramları, E. Mutlu (der. ve çev.), Ütopya Yayınevi, Ankara, ss.233-239.

KÖYLÜ, M. (2012). “HIV/AIDS İle Mücadelede En Büyük Sorun Virüs Değil, Önyargılar", Nefret Söylemi velveya Nefret Suçları, Y. İnceoğlu (der.), Ayrıntı Yayınları, İstanbul, 325-343.

LLOYD, G., (1996). Erkek Akıl - Batı Felsefesinde 'Erkek' ve 'Kadın', M. Özcan (çev.), Ayrıntı Yayınları, İstanbul.

LUNDBY, K. \& Roonning, H. (1997). “Medya-Kültür-İletişim: Medya Kültürü Aracılığıyla Modernliğin Yorumlanışı", N. Gürkan (çev.), Medya Kültür Siyaset, S. İrvan (der.), Ark Yayınları, Ankara, ss.13-28.

MAIGRET, E., (2011). Medya ve İletişim Sosyolojisi. H. Yücel (çev.), İletişim Yayınları, İstanbul. 
MUMBY, D. K., (2005). “İdeoloji ve Anlamın Toplumsal İnşası: Bir İletişim Bakış Açısı", Ç. Dursun (çev.), Doğu Batı, Kasım-Aralık-Ocak 20042005, ss.123-141.

ONG, W. J., (1995). Sözlü ve Yazılı Kültür - Sözün Teknolojileşmesi, (çev. S. P. Banon), Metis Yayınları, İstanbul.

ÖRDEK, K. (2012). "Türkiye'de Trans Bireylere Yönelik Nefret Suçları", Nefret Söylemi velveya Nefret Suçları, Y. İnceoğlu (der.), Ayrıntı Yayınları, İstanbul, 307-324.

PELIZZON, S. M., (2009). Kadının Konumu Nasıl Değişti? - Feodalizmden Kapitalizme, İ.E. Sadi \& C. Somel (çev.), İmge Kitabevi, Ankara.

SCOTT, J. W., (2007). Toplumsal Cinsiyet: Faydah Bir Tarihsel Analiz Kategorisi, A.T. Kılıç (çev.), Agora Kitaplığı, İstanbul.

ÜŞÜR, S. S., (1997). İdeolojinin Serüveni - Yanlış Bilinç ve Hegemonyadan Söyleme, İmge Kitabevi, Ankara.

YENGİN, D., (2012). Yeni Medya ve Dokunmatik Toplum, Derin Yayınları, İstanbul.

ZEYBEKOĞLU, Ö., (2013). Toplumsal Cinsiyet Bağlamında Erkeklik Olgusu, Eğiten Kitap, Ankara. 


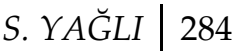

